\title{
DOES VITAMIN C AFFECT HBA1C?
}

\author{
Dwi Astuti Dian Andarwati' ${ }^{1}$, Bhisma Murti²), \\ Endang Sutisna Sulaeman²) \\ 1)Masters Program in Nutrition, Universitas Sebelas Maret \\ 2)Masters Program in Public Health, Universitas Sebelas Maret
}

\begin{abstract}
Background: Diabetes is a chronic disorder associated with disturbances in carbohydrate, fat, and protein metabolism characterized by hyperglycemia. HbA1c is used to monitor long-term glycemic control, adjust therapy, assess the quality of diabetes care, and predict the risk for the development of complications. Early studies showed that vitamin $\mathrm{C}$ increases inflammation and oxidative stress as a strategy to prevent diabetes. This study aimed to examine the effect of vitamin $\mathrm{C}$ on HbA1c.
\end{abstract}

Subjects and Method: This was a literature review study. The literature was obtained from ScienceDirect, PubMed, and Google Search. After screening of articles published from 2000 to 2018 using keywords "HbA1c" and "vitamin C", the author obtained 21 articles. The study population was diabetic and non-diabetic patients.

Results: Almost all research articles under review showed inverse relationship between vitamin $\mathrm{C}$ and HbA1c. That said, the higher vitamin $\mathrm{C}$ consumption, the lower HbA1c. This is because vitamin $\mathrm{C}$ can reduce microvascular complication and cardiovascular disorder in diabetic and non-diabetic patients. In non-diabetic patients, vitamin $\mathrm{C}$ can reduce the risk of diabetes. In diabetic patients, it can reduce the risk of diabetes complication.

Conclusion: High dose of vitamin $\mathrm{C}$ decreases HbA1c level. Vitamin C can help reduce risk of diabetes as well as diabetes complications.

Keywords: diabetes, HbA1c, vitamin C

\section{Correspondence:}

Dwi Astuti Dian Andarwati. Masters Program in Nutrition, Universitas Sebelas Maret, Surakarta 57126, Central Java. Email: dianandarwati@yahoo.com. Mobile: o81329588344. 